Conference Circuit

\title{
The scholarly monograph in crisis
}

\author{
By Barbara Halporn
}

\section{How can I get tenured if you won't publish my book?}

$\mathbf{T}$ he Specialized Scholarly Monograph in Crisis or How Can I Get Tenure if You Won't Publish My Book?" sponsored by the American Council of Learned Societies (ACLS), the Association of American University Presses, and the Association of Research Libraries was held in Washington, DC, September 11-12, 1997.

Rarely does a conference produce sessions that are as lively and engaged as the corridor conversations between acts, but the "Monograph in Crisis" was the exception to prove the rule. Some 150 individuals representing scholarly publishing, the professoriate, and research libraries met ostensibly to discuss the relationship between tenure and the dwindling market for scholarly monographs. To everyone's profit, the presenters and the participants quickly expanded the discussion to the current status and future of scholarly publication in general, the uncertainties of traditional print publication in an electronic environment, questions of who readers will be and how they want to get information, how it is to be packaged and sold, and how libraries will acquire it.

The panel offerings fell into these categories: overview of scholarly communication issues; the economics of scholarly publishing; changing expectations for faculty; experiments in monographic publishing; new frameworks for scholarly research and communication; future directions.

The scholarly publishers introduced us to the hard economic truths of their (and our) world. Joanna Hitchcock, director of the University of Texas Press and president of the AAUP, reminded us that the original mission of university presses was to publish the results of advanced research for specialists, work that had no place in the commercial market. Universities that once subsidized their presses to enable them to fulfill that mission now demand that their presses be self-supporting. Consequently, university presses have looked for broader audiences (i.e., outside the academy) with more diversified (i.e., more popular) lists. Shifts in scholarship from focus on America and western Europe to greater geographical, cultural, and chronological range have created greater diversity in lists but smaller audiences for specialized publications. Scholarly presses must weigh carefully the risks in publishing a specialized monograph with a limited market.

Just what the risks are became clear when Marlie Wasserman, director of the Rutgers University Press, answered the question, "How much does it cost to publish a monograph and why?" Corridor conversations with others in publishing confirmed the gloomy picture of declining print runs and sales of scholarly books, where sales of 500 copies are considered a success even if they make no profit. Publishers have cut costs as deeply as they can. The mode of production-print or electronic-accounts for only a third of the cost of production.

Sanford Thatcher, director of the Pennsylvania State University Press, pointed to the "divergence of scholarly value and market value." Both Thatcher and Colin Day, director of the University of Michigan Press, emphasized the interdependencies in the system of scholarly communication, the need to think about the system as a whole, and how change in one area affects many other areas. When, for example, authors produce camera-ready copy, they must divert attention from their primary skills and tasks (scholarship and teaching) to do work that publishing professionals are best 
equipped for. The costs are high to the system as a whole, even if they ease the economic pressures on the publisher.

Speakers defined the monograph in a variety of ways, both serious and facetious. Among other things it was called "comotose," "chronically ill," "the representative of the scientific tradition in humanistic scholarship," "the solid thud on the desk of the dean that backs up a case for tenure," and "200 library sales, no course use, intended for specialists."

The subtitle of the conference-"How Can I Get Tenure If You Won't Publish My Book?"gradually took a subordinate role to discussions of the crisis in scholarly publishing in general, probably because the professoriate was underrepresented in the audience. Although several panelists discussed the role of publishing in tenure decisions, these discussions were not as intense as those that spoke to publishers and librarians, who accounted for more than three-quarters of the participants. Nevertheless, John D'Arms, president of the ACLS, Charles Beit $\%$ dean for academic affairs at Bowdoin College, and Peter Nathan, acting president of the University of Iowa, spoke candictly about the need to support junior faculty, to develop a better system to evaluate for tenure, and to prepare graduate students and postdoctoral students to enter the academic system.

Several innovative publishing partnerships were described (one print, three electronic), exploring new models for publishing in the future. The Mellon Foundation has underwritten the research and development of several electronic publishing projects, which must at some point make it independently.

The conference concluded with a look at the future. At Clifford Lynch's prediction that print would not disappear but that ways of getting information would be "more and different," a visible sense of relief spread through the room. In his view, we will learn how much users value publishers' "added value." He suggested that the notion of single authorship in the humanities may give way because it becomes increasingly difficult to allocate credit on work that develops through constant e-mail collaboration. This could transform the modes of rhetorical strategies in scholarly argument and in the long run perhaps create a new style of scholarly monograph.

Sanclria B. Freitag, executive director of the American Historical Association, described the roles that the institutional actors may play in the arena of scholarly publishing. Gatekeeping, quality control, and peer review remain critical features of the scholarly process. She sees an increasing role for scholarly societies in shaping the direction of publication in the humanistic disciplines if they will take up the challenge of figuring out how best to use the medium to enhance scholarly value. As a backdrop to the conference, the September 12, 1997, Chronicle of Higher Education published two articles on issues central to the conference: $V$. Kiernan's "University Libraries Debate the Value of Package Deals on Electronic Journals" (A31A33) and K. Wissoker's "Scholarly Monographs Are Flourishing, Not Dying" (B4-135). Kiernan reported the unease that librarians experience with package deals on electronic journals. Wissoker, the editor-in-chief of Duke University Press, challenged the premise of the conference by asserting that scholarly publishing is in the throes of change, not death.

The conference was a lively, intelligent, and long-overdue conversation among scholars, publishers, and librarians. If the papers of this are published, they will be worth revisiting.

\section{Statement of ownership and management}

College E Research Libraries News is published 11 times a year (monthly, combining July/August) by the American Library Association, 50 E. Huron St, Chicago, IL $6061 \mathrm{l}$. American Library Association, owner; Mary Ellen K. Davis, editor and publisher. Second-class postage paid at Chicago, Illinois. Printed in the U.S.A. As a nonprofit organization authorized to mail at special rates (DMM Section 423.12), the purposes, function, and nonprofit status of this organization and the exempt status for federal income tax purposes, have not changed during the preceding 12 months.

Extent and nature of circulation. "Average" figures denote the number of copies printed each issue during the preceding twelve months: "Actual" figures denote the number of copies of single issues published nearest to filing date.) Total number of copies printed (net press nin): Average, 12,380; Actual. 12,322. Sales througb dealers and carriess, streel vendors, and connter sales: not applicable. Paid or requested mail subscriptions: Average, 11,655; Actual, 11,712. Total paid and/or requested circulation: Average, 11,655; Actual, 11,712. Free clistribution by mail: Average 107; Actual, 111. Free distrihution outside the mail: Average, 1); Actual, 0. Total free distribution: Average, 107; Actual, 111. Total distrihution: Average, 11,762; Actual, 11,823. Copies not distributed: Office use, leftover, spoiled: Average, 618; Actual, 499. Retums from news agents: not applicable. Total (sum of previous entries): Average, 12,380; Actual, 12,322. Percent paid and/or requested circulation: Average: $99.09 \%$; Actual: $99.06 \%$.

Statement of Ownership, Management, and Circulation (PS Form 3526, October 1997) for 1997 filed with the United States Postal Service, Postmaster in Chicago, Illinois, October 6, 1997. 

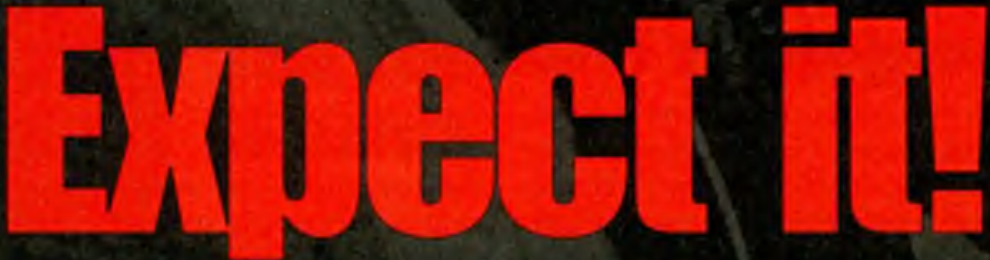

Looking for a powerful, new, turnkey, fully-integrated library automation system that's rich in features, high in efficiency and low in maintenance? Want it to be a proven winner with libraries nationwide? Need it to perform in a Windows NT, Intel server, and Internet environment?

\section{YOU'RE NOT ALONE.}

When it comes to cutting-edge library automation delivered with exceptional service, today's disceming librarians increasingly expect it and demand more!

\section{Library Solution}

And, that's precisely why TLC has created its highly acclaimed, authority controlled new systemLibrary-Solution! As libraries across the U.S. are now finding, Library Solution is a feature-intensive, cost-efficient, single-source option for librarians to meet all their automation needs.

Better yet, you won't have to wait until next year to get started. Library-Solution is available - NoWI

Just as important, it's from The Lbrary Corporation-which for more than 20 years has been delivering innovative client solutions, with superior customer service. At TLC we're:

- Proud developers of Bibliofile software

- Creators of Library.Net, a revolutionary Internet service helping libraries establish customized sites on the World Wide Web

- The only company to provide free access to the Cataloger's Reference Shelf via the Internet

- Creators of NetPAC, a state-of-the-art service providing patrons unlimited access to a library's public access or consortium catalog via the Web

So, if you're considering what library automation company to select as your partner, we hope you'll expect it and demand more! TLC, committed to delivering solutions that enable libraries to provide a more rewarding experience for their patrons.
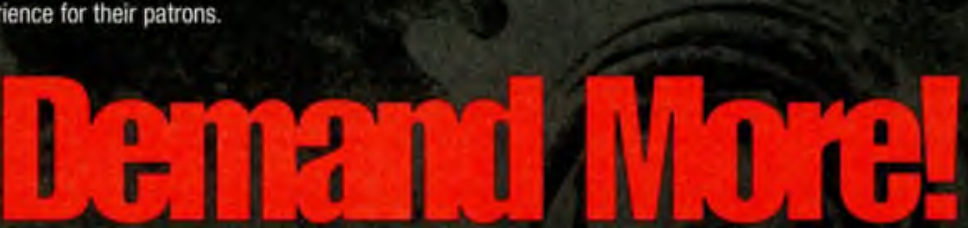

TLC - Research Park - Inwood, WV 25428-9733

TEL: 304.229 .0100 - FAX: 304.229.0295 - TOLL FREE: 800.325.7759 - E-MAlL: InfoeTLCdeliver5.com - WEB: www.TLCdelivers.com 